\title{
Underemployment in South Africa
}

ROCHELLE BEUKES, TINA FRANSMAN, SIMBA MUROZVI AND DEREK YU

\section{Stellenbosch Economic Working Papers: 06/16}

KEYWORDS: UNDEREMPLOYMENT; UNDEREMPLOYED; SOUTH AFRICA

JEL: J 00

$$
\begin{gathered}
\text { ROCHELLE BEUKES } \\
\text { DEPARTMENT OF } \\
\text { ECONOMICS } \\
\text { UNIVERSITY OF THE } \\
\text { WESTERN CAPE } \\
\text { SOUTH AFRICA } \\
\text { E-MAIL: } \\
\text { RGALLANTOI@GMAIL.COM }
\end{gathered}
$$

$$
\begin{aligned}
& \text { TINA FRANSMAN } \\
& \text { DEPARTMENT OF } \\
& \text { ECONOMICS } \\
& \text { UNIVERSITY OF THE } \\
& \text { WESTERN CAPE } \\
& \text { SOUTH AFRICA } \\
& \text { E-MAIL: } \\
& \text { 3120950@UWC.AC.ZA }
\end{aligned}
$$
SIMBA MUROZVI DEPARTMENT OF ECONOMICS UNIVERSITY OF THE WESTERN CAPE SOUTH AFRICA E-MAIL:

SMUROZVI@GMAIL.COM
DEREK YOU DEPARTMENT OF ECONOMICS UNIVERSITY OF THE WESTERN CAPE SOUTH AFRICA E-MAIL: DYU@UWC.AC.ZA

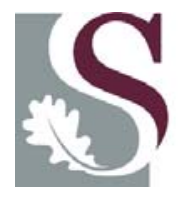

\section{UNIVERSITEIT STELLENBOSCH UNIVERSITY}

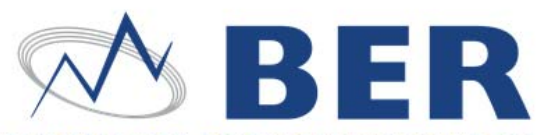

BUREAU FOR ECONOMIC RESEARCH

A WORKING PAPER OF THE DEPARTMENT OF ECONOMICS AND THE BUREAU FOR ECONOMIC RESEARCH AT THE UNIVERSITY OF STELLENBOSCH 


\section{Underemployment in South Africa}

ROCHELLE BEUKES, TINA FRANSMAN, SIMBA MUROZVI AND DEREK YU*

ABSTRACT

With the introduction of the Quarterly Labour Force Survey (QLFS) since 2008, a newly derived variable, namely underemployed, has become available. This variable is derived according to the "time-related" approach (i.e. those who are employed, but would like to work longer hours and are available to work longer hours in the near future). However, underemployment could also be derived according to the "inadequate employment situations" approach (e.g. underutilisation of skills, over-qualification). There are virtually no in-depth local studies that examine underemployment in South Africa. Hence, this paper investigates the extent of underemployment according to two definitions, before examining whether the characteristics of the underemployed are significantly different from those of the other employed.

Keywords: underemployment; underemployed; South Africa JEL codes: J00

${ }^{*}$ This paper is also available as ERSA Working Paper 575. The authors acknowledge financial support for this project from Economic Research Southern Africa (ERSA). 


\section{Introduction}

Since the dawn of democracy, policy changes to promote equality have been occurring in spheres such as education, health care and within the labour market. There have been numerous measures enforced by the South African government with the aim of, amongst others, reducing unemployment, inequality, labour market discrimination and rigidities. South Africa has come a long way in correcting these imbalances of the past but this task has proven to be no easy feat.

One of the major socio-economic issues South Africa is still grappling with to date remains the persistently high level of unemployment (5.5 million labour force were unemployed, while unemployment rate was $26.3 \%$ in the first quarter of 2015). Consequently, one of the most important and recurring goals emphasised by government on various platforms such as the New Growth Path (NGP) and the National Development Plan (NDP) is job creation. Over the years, labour market analysis has focused mainly on the employed versus the unemployed with job seekers and discouraged work-seekers also being accounted for. However, as the labour market grows in terms of complexity, the distinction between being employed and unemployed has proven to be inadequate. Also, economic policies around job creation always seem to focus on increasing the number of jobs created each year or setting out goals to create a certain number of jobs within a particular period. However, little attention is paid to the extent to which jobs occupy people in terms of hours and the way in which it utilises their skills and qualifications. The capacity of the labour force is therefore often disregarded.

Labour agencies in various developed countries have seen the need to consider that unemployment rates may not be an adequate measure of labour under-utilisation. There may be many individuals who are employed, but their labour may not be fully utilised based on various definitions of underemployment. This presents an issue for economists, as the under-utilised labour is not recoverable. Even more unsettling is that the loss of skills and future career path consequences for individuals may be hampered for a longer duration than is expected, impacting the labour force in a manner that could exacerbate structural problems in an economy.

With the introduction of the Quarterly Labour Force Survey (QLFS) since 2008, two new variables were derived by Statistics South Africa (Stats SA). One of them, of which this paper will be based on, is known as the underemployment variable. Initially this variable only referred to what is termed the time-based approach, which in brief terms relates to individuals who are employed and are willing and able to work longer hours but cannot for various reasons. In addition to this, the underemployment variable can also be analysed in the context of the "inadequate employment situations" approach which highlights the under-utilisation of skills or over-qualification (to be discussed later). If someone is underemployed, this may suggest that labour, as a factor of production, is being under-utilised. Due to the derivation of the underemployment variable, distinguishing the employed from the unemployed now only paints one fragment of the picture in the context of the South African labour market.

To date, the majority of existing studies focus on the characteristics of the unemployed, the causes of unemployment and policy options to alleviate unemployment (Kingdon and Knight 
2004; Banerjee, Galiani, Levinsohn, McLaren and Woolard 2008; Bhorat 2009 \& 2012). However, there is a need to investigate underemployment in South Africa as there are currently only three local studies on it (to be discussed later). This shows that underemployment is still very much an under-researched topic. This can be attributed to the fact that the variable is still considered to be quite newly derived when compared to other variables. Hence, this study aims to provide a preliminary analysis on the profile of the underemployed.

In this study, the term "underemployment" will be related to two definitions, namely the timebased approach and the inadequate employment situations approach which will be elaborated at a later stage. With this in mind, the question can be posed that perhaps the labour market segmentation should be re-examined after taking underemployment into consideration.

The rest of the paper is structured as follows: Section 2 presents both a conceptual as well as a theoretical framework. The conceptual framework looks at how the underemployment variable is defined locally versus internationally and also highlights the two main approaches adopted in relation to the two definitions. The theoretical framework presents a brief discussion of the various theories that can the related to underemployment. A literature review of the past local and international studies is also presented in this section. Section 3 explains the methodology and data as well as the results of the empirical data analysis on the profile of the underemployed. Section 4 concludes the study.

\section{Literature review}

\subsection{Conceptual framework}

Over the years, how underemployment has been understood has differed from person to person. For this reason the derivation of this variable to a large extent can be considered as being subjective. The results obtained from an analysis of underemployment are predominantly dependant on the way in which it is defined. A formal definition of underemployment has also been adopted by Stats SA since 2008. It was only with the introduction of the QLFS in 2008 that the new variable of underemployment became available. Underemployment definitions may differ in terms of certain specifically defined criteria that must be satisfied. Since the aim of the paper is to study underemployment in the context of South Africa, it is important to know how underemployment is defined both locally as well as internationally.

Underemployment affects the employed segment of the labour force when it occurs. There are two common approaches which have been adopted to distinguish different types of underemployment, namely time-based (time-related) approach and inadequate employment situations approach. According to the time-based definition, underemployed refer to those employed who work fewer hours than they wished for. For this paper, the inadequate employment situations approach will solely investigate over-qualification and skills mismatch. It generally refers to the situation where workers find themselves in professions or jobs where their skills, training and experience are under-utilised (Bonnal, Lira and Addy, 2009:217). This in turn implies that these persons are not given the opportunity to fully utilise their productive ability. 
Based on the QLFS, Stats SA defines underemployment as the situation where persons who are willing and available to work additional hours, only actually worked fewer than 35 hours during the reference week ( $\mathrm{Yu}, 2009: 20)$. These individuals must be able to start work within the next four weeks. In other words, the time-based approach is adopted by Stats SA. With reference to the South African context, statistics prove that underemployment is on the rise and in the face of an increasing unemployment rate should raise concern about the state of the country's labour market.

The crux of underemployment in terms of a formal definition which is considered to be the internationally accepted definition refers to persons who has a job during the reference week or had worked during the reference week who were both available as well as willing to work "more effectively" (Greenwood, 1999:3). In relation to the terms "more effectively", this in essence refers to the situation where the labour provided by workers are not utilised as effectively as it could have and should have been utilised (Wilkins and Wooden, 2011:14).

According to the International Labour Organization (ILO), those defined as underemployed according to the time-based definition refer to individuals who, during the reference week, were both willing to work additional hours and available to work these additional hours. However, in reality they worked fewer than a certain number of hours (Greenwood, 1999:4). The threshold with respect to the number of hours a person must work before they are considered to be underemployed could differ from country to country, and may be influenced by collective bargaining agreements or labour legislation. As earlier mentioned, this threshold in South Africa is deemed to be 35 hours a week.

The ILO defines the inadequate employment approach as the situation where persons who during the reference week desired to change their existing work situation. This had to firstly be on condition that their current work situation limited both their competencies and their wellbeing and secondly on condition that they were actually available to do so (Greenwood, 1992:8). As stated by Wilkins and Wooden (2011:16), the ILO actually noted that the definition related to the inadequate employment approach is in reality unable to be implemented. For this reason, they endorsed the development of indicators to measure three explicit types of inadequate employment situations namely, skills-related underemployment; excessive working hours and income-related underemployment. For the purpose of this study, the inadequate employment approach will only examine skills-related underemployment which will specifically examine skills under-utilisation or over-qualification.

Skills under-utilisation or over-qualification is not uncommon within the labour market. It often occurs if persons find themselves in a particular work situation where the qualifications and skills they possess are too advanced (Kazan, 2012:1). The reason for this is due to the fact the tasks and competencies their job requires them to do and have respectively, does not require "that level" of expertise and skill. As a result, the person is likely to find themselves in a job where their full productive capacity is not being utilised as it should, and hence it being referred to as the under-utilisation of skill as the person is over-qualified for the position. 
In terms of the other ways in which underemployment can be described, reference has been made to underemployment as being either qualitative or quantitative. Qualitative underemployment refers to individuals who have no choice but to accept employment associated with a level below his or her qualification as well as skill level and experience. This in turn implies lower remuneration. Alternatively, quantitative underemployment is the situation where individuals find themselves in employment where the amount of hours they are required to work is less than the number of hours that they desire to work. This is often found in the case of nonvoluntary part-time work for example (Ruiz-Quintanilla and Claes, 1994: 5). Hence, it is evident that qualitative underemployment relates to the inadequate employment situations approach, while quantitative underemployment relates to the time-based approach, as discussed above.

Visible and invisible underemployment could also be distinguished. By definition, visible underemployment refers to persons who work less than normal hours on an involuntary basis. These are individuals who are seeking, or desire working additional hours or on a full-time basis. On the other hand, invisible underemployment refers to the situation where there is a misallocation of labour resources. This misallocation implies workers with low levels of productivity or the underutilisation of skills (Barker, 2007: 177). It can therefore be noted that visible underemployment in essence refers to time-based underemployment while invisible underemployment refers to skills-related underemployment.

Skills-related underemployment could also be further classified into as intra-skill and inter-skill underemployment (Glyde, 1977: 258). Intra-skill underemployment occurs when individuals who belong to a particular skill group are unable to utilise their skills in the same way as the others in the same skill group. Reasons for this do not pertain to the demand for those particular skills, instead it may refer to factors such as discrimination by employers or the way in which those individuals are perceived in terms of his or her ability and the corresponding cost associated with the employment of these individuals. In contrast, inter-skill underemployment refers to the situation where individuals in a particular skill group have trouble employing a particular skill due to the fact that it is less sought-after when compared to other skills that entail the same investment cost.

According to McGuinness (2006), over-qualification can be measured using four approaches of which two are considered to be objective while the remaining two are considered to be subjective. The first subjective approach firstly pertains to asking the worker directly whether he/she perceives he/she is over-educated or not. The second subjective approach entails asking the worker to make a comparison between his/her own subjective assessment of the minimum education requirements of his/her current job and to his/her attained education level (Wilkins and Wooden, 2011: 26).

In the first objective approach, an employed is regarded as being overqualified if his/her years of education are one standard deviation above the mean years of education associated in his/her relevant occupation category (McGuinness, 2006: 396). The use of this one standard deviation method is being used more frequently even though arguments exist which state that measures based on occupation mode instead of mean is more likely to be desired (Wilkins and Wooden, 2011: 25). On the other hand, the second objective approach assesses over-qualification by 
determining the education level required by an individual in relation to his/her job title and then making a comparison of this required educational level with his/her actual education level. This can be done by making use of information obtained from professional job analysts. In South Africa, the information on the required educational level in each broad occupation category can be obtained from the South African Standard Classification of Occupations (SASCO).

The objective approaches may seem to be better than the subjective approaches, but they are not without criticism. The measurement of over-qualification by means of the standard deviation approach has undergone criticism as the choice of cut off points is arbitrary. In addition to this, since the standard deviation method makes use of the assumption of symmetry, it has been argued that it is unrealistic. Lastly in the situation where a certain occupation comprises of a large proportion of workers, who are classified as being overeducated, will result in an underestimation of the actual level of over-qualification. This is attributed to the fact that the high proportion of overeducated workers will bring about a rise in the occupational average as well as the associated cut-off points (McGuinness, 2006: 396). Alternatively, in the case of the occupation dictionary approach, it has also been criticized for being unrealistic. One reason for this is centred on the fact that this approach works under the assumption that the educational requirements are the same for all jobs that fall within the same occupation code. Furthermore, these dictionaries are not updated on a regular basis and as a result the assumption is made that job requirements are constant over time. Finally, even at extremely disaggregated levels, heterogeneity exists within occupations (Wilkins and Wooden, 2011: 25).

Based on the various definitions of underemployment, it is possible to identify the main characteristics that the underemployed are associated with, such as low levels of remuneration, short working hours, over-education, skill-underutilisation and a mismatch between skills and knowledge (Reynolds, 2012:7). By considering these characteristics, it is evident that various economic along with social consequences will follow. For that reason, amidst the rising unemployment rate, underemployment should not be disregarded. Even though the underemployed may be employed in the true sense of the word, underemployment paints a picture of an inefficient labour market.

Few studies have even referred to the unemployed as being part of the underemployed (Clogg, Mutchler and Sullivan 1986; Slack and Jensen 2002). However, based on the way in which underemployment has been defined in this paper, the unemployed would not form part of the underemployed, i.e. underemployment only occurs on condition that an individual is employed.

Finally, underemployment brings about a number of consequences relating to economic outcomes as well as measures of the general well-being of individuals. More specifically, these consequences refer to life satisfaction and job satisfaction in terms of the general well-being of individuals while negative effects on wages or income are associated with consequences relating to economic outcomes of individuals (Wilkins and Wooden, 2011: 25).

\subsection{Theoretical Framework}

One would initially consider the underemployed to be better off than the unemployed. The reasoning behind this belief is that these individuals still receive an income as they form part of 
the labour force (Wilkins, 2007: 284). This type of reasoning is however misleading and does not really take into account both the economic and social implications of underemployment. These individuals are more likely to be associated with fewer working hours, lower wages and as a result, a lower level of welfare. From a theoretical point of view, it has already been established that the underemployed are considered to be outsiders within the context of labour market theory.

Figure 1 represents a graphical illustration of those who are underemployed according to the time-based definition. Assume the person sleeps 8 hours per day and spends the remaining 16 hours on either work or leisure. This person, who is currently employed, would have preferred to work 11 hours per day (as indicated by the equilibrium at point $\mathrm{A}$ ), attaining a utility level of $\mathrm{U}_{3}$. However, this individual is unfortunately only offered employment that requires him or her to work only 3 hours per day (represented by point B). As a result, this person only attains a lower utility level of $\mathrm{U}_{1}$. In other words, the person is underemployed at point $\mathrm{B}$, as he/she would have loved to work an additional 8 hours every year. It is also evident that fewer hours of employment are associated with a lower wage income $\left(\mathrm{Y}_{1}\right)$ as compared to the prospective income that the individual could have received $\left(\mathrm{Y}_{2}\right)$ had he been fully employed (working 11 hours).

\section{[INSERT FIGURE 1 ABOUT HERE]}

The examination of skills under-utilisation or over-qualification may spark thoughts of the human capital theory. As stated by the theory, one would expect the investment in education and training to bring about better labour market outcomes. The presence of skills-related underemployment therefore may implicitly contradict this theory. To make this clearer, Figure 3 represents a graphical illustration of those who are underemployed under the over-qualification definition. As mentioned previously, this refers to the situation where a person finds himself or herself in a particular job where the skills requirements are below their level of qualification (Sengenberger, 2011:11).

\section{[INSERT FIGURE 2 ABOUT HERE]}

In this case one can recall the human capital theory which states that the investment in education is likely to being about an increase in both productive potential as well as incremental earnings. With reference to the figure, in the case where the individual has a Bachelor Degree, he or she would want to be offered a higher wage $\left(\mathrm{W}_{2}\right)$ which in turn implies that this individual is expected to be employed in a highly-skilled occupation. The individual therefor hopes to attain a utility of $\mathrm{U}_{3}$ which is found at equilibrium point $\mathrm{A}$, and earns a total wage income of $\mathrm{Y}_{2}$ by working 10 hours per day. However, the individual eventually could only find employment in a semi-skilled occupation which actually requires a lower educational qualification (e.g. Matric) than the level he possesses (Bachelor Degree). This job is in turn accompanied by a lower wage $\left(W_{1}\right)$ which means that the equilibrium point will now be at point $B$. This point is also associated with a much lower level of utility $\left(\mathrm{U}_{1}\right)$ and total wage income $\left(\mathrm{Y}_{1}\right)$, even though the daily work hours remains the same at 10 hours. 
Researchers, from a theoretical perspective, have also associated this under-utilisation of skills with notions of misalignment in terms of person-job fit. Person-job fit, as the name indicates how well the skills and competencies of an employee matches their job and its demands (McKeeRyan and Harvey, 2011:971). Based on this theory, underemployment indicates a lack of fit and as a result is associated with negative labour market outcomes. Relating this back to the budget line/indifference curve analysis, the fact that the employee was only able to find semi-skilled employment instead of highly-skilled employment related to his or her field of study verifies the situation of a misalignment between the skills and competencies of the person and their job. Furthermore, in line with the analysis, negative labour markets outcomes can refer to the lower level of utility experienced by the employee and lower remuneration, as already discussed above.

And so it can be said that time-based and skills-related underemployment in the context of this study can be related to theoretical foundations relating to human capital, welfare and person-job fit. The analysis conducted indicates that both time-related and skills-related underemployment brings about less favourable labour market outcomes and proves the presence of labour market inefficiencies.

\subsection{Review of past studies}

There are only three local studies at the time of writing. In the study by $\mathrm{Yu}$ (2009), underemployment is briefly discussed. He found that in the first three QLFS data sets of 2008, the underemployment variable was derived incorrectly (Stats SA later re-derived this variable correctly). He also found that the underemployed according to the time-based definition accounted for about $4.5 \%$ of all employed. The majority of underemployed are Blacks and females (approximately 85\% and 60\% shares respectively). Yu (2009:20) also found that nearly $60 \%$ of underemployed are involved in unskilled occupations.

In an unpublished study by Mathebula (2013), he considered the determinants of time-related underemployment using the 2012 QLFS 3rd quarter data. Univariate as well as multivariate analysis was done. Mathebula (2013:3) found that females, those without post-Matric qualifications, residing in urban areas, with limited or unspecified contract duration were more likely to be underemployed. Underemployment likelihood was also the highest for those involved in the community, social, personal services as well as real estate, financial intermediation, insurance and business services occupation categories (Mathebula, 2013:4).

Schoeman, Botha and Blaauw (2010) noted that structural shifts and technological change caused a shift in output from primary to service sectors, and technological adjustment resulted in an increase in capital/labour ratios. The objective of their study was to analyse the role that labour conflict plays in macro underemployment in South Africa. Two forms of labour conflict were considered, namely distributional and relational conflicts. Their model set out to determine capital/output ratios as explained by distributional and relational conflict (Schoeman et al, 2010: 279). Data was obtained from the South African Reserve Bank and Quantec Research for the period 1970-2004. Variables included capital/output ratios; compensation for employees; gross value added; interest rates; and inflation rates. Data on the frequency of strikes was obtained from Van der Velden. They (2010: 286) found that labour conflict originates from an overregulated labour market and bad labour relations. Underemployment results through a 
switch in technology being the channel. Bad labour relations have shown to contribute to the choice of more capital-intensive techniques and hence less labour absorptive measures. The cointegration analysis showed that once labour has been replaced by capital, a reversal is not likely (Schoeman et al, 2010: 286). Capital is highly inflexible even in the long run. Thus the long-term effects on underemployment due to structural reasons in an economy cannot be easily remedied.

Numerous international studies have been done to investigate the extent and nature, predictors and consequences of underemployment. Definitions and approaches to measure underemployment differ significantly hence international comparisons may be difficult.

First, Golub and Hayat (2014) cited the main reason for underemployment in Africa as a dualistic labour market that is deficient of labour demand. A predominance of informal sector employment and agricultural activities exists, which results in underemployment rather than open unemployment (Golub and Hayat, 2014: 2). In a report presented at the G20 Labour and Employment Ministerial Meeting (OECD 2014:7), underemployment is noted to be characterised by workers employed in informal, low-paid, low-productivity employment. Informal activities were typically characterised by agriculture, non-wage employment and parttime work. It was found that informal employment in many low-income Sub-Saharan African countries accounts for $80 \%$ of total employment. The formal sector has been weak in creating sufficient jobs to absorb a growing workforce, thereby resulting in growing underemployment ${ }^{2}$.

Wilkens and Wooden (2011) provide a review of existing literature. Even as many national statistical agencies report on time-based underemployment, definitions vary across countries. Within the OECD, a group of countries who participated in the European Labour Force Survey of 2008 used the same time-based definition, which relates to involuntary part-time work. In the study, the incidence of underemployment ranged from $0.4 \%$ in Hungary to $4.3 \%$ in Italy. On the other hand, the UK study by Bell and Blanchflower (2013) also used the time-based definition, asking workers if they feel constrained by their working hours. An underemployment index was created to capture excess labour capacity. Their index was a more general unemployment rate as the willingness of workers to supply extra hours was counted (Bell and Blanchflower, 2013:5). The results showed that underemployment has risen sharply since the recession in 2008. Tam (2010) similarly found that the underemployment rates in UK rose during the recession period as labour demand declined. The incidence of underemployment was found to be higher among young, under the age of 25.

Walling and Clancy (2010) as well as Cam (2014) also focus on underemployment in the UK. It was found that underemployment likelihood was typically higher for women than men, but varies across demographics and work related factors. Those involved in part-time jobs, sales, and customer services were associated with a greater likelihood of underemployment (Cam, 2014:15). In contrast, Sengenberger (2011) found that time-based underemployment rose over the period 1990-2005 although results varied across countries. Time related underemployment was also

\footnotetext{
${ }^{2}$ No clear definition is provided for underemployment in this study. However the informal sector, which accounts for most employment activities, is defined as non-wage, part-time and agricultural activities. This allows us to infer that both time-based underemployment and loss of income define underemployment.
} 
higher for women than men. Wilkens (2006) similarly found underemployment to be more prevalent among females.

In the study by Ansah (2012), a review of Ghana's national employment policy was undertaken. Most of the employment activities took place in agriculture and the informal economy. It was found that the rate of underemployment as defined by the ILO under the time-based approach was higher in urban areas at 7.6\% versus rural areas at 3.5\% (Ansah, 2012:109). In the study by Denu, Tekeste and Van der Deijl (2005), they examined the employment characteristics of youth in Ethiopia, and found serious under-employment in rural areas, as the mean weekly work hours of rural youth employed were 21.3 hours, compared to 36.8 hours for urban youth employed.

When considering the over-qualification definition, researchers typically adopted either objective measure or subjective measures as discussed in Section 2.1. First, Felstead and Green (2013) examined the 2012 UK survey data to determine the extent of qualification mismatch with the job as according to the respondent. They found higher rates of over-qualification for youth aged 20-24 years, those engaged in part-time work and those participating in services industries. Fleming and Kler (2008) used the Australian survey data and found that 34.36\% of employed were overeducated. These people were mainly young adults, working fewer hours, but having formal qualifications with limited experience.

Wilkens and Wooden (2011) argued that the problem with comparing the educational requirement of a job to that of what an individual holds is that standards are rarely updated. McGuinness (2006) raised the issue that the same occupations may require differing skills. The education levels of workers may also increase, resulting in workers allocated differently. This was echoed by Felstead and Green (2013) who found that individuals are becoming more educated than the jobs created requiring certain skills. In their study the supply of graduates was outpacing the new graduate jobs created.

Mosca and Wright (2011) considered graduate underemployment in the UK. A panel dataset was constructed for those graduating in 2002/3. The rate of "non-graduate job" employment was calculated twice, at 6 and 42 months after graduation respectively. To distinguish a non-graduate job, the skills requirement for various occupations as stipulated by the Standard Occupation Classification was consulted (Mosca and Wright, 2011:3). If a graduate was employed in an occupation with a skills requirement lower than a Bachelor Degree, it constituted underemployment. Although graduate underemployment declined, about a quarter of graduate employed were still involved in non-graduate jobs 3.5 years later (Mosca and Wright, 2011:7). Individual characteristics were more so important at explaining underemployment at 6 months as opposed to 42 months. Explanatory variables such as quality of institution, subject of study, award classification were all statistically significant in the econometric analysis. An important finding was that being in graduate employment at 6 months after graduation had a significant effect on being involved in graduate employment at 42 months. The first job a graduate involved in may have an impact on occupational attainment later in their career paths.

Other researchers found similar results as those of Mosca and Wright (2011); that overeducation may have lasting effects on graduate employment in the future. For instance, Reynolds 
(2012) examined the incidence, causes and consequences of youth underemployment in Canada in 1997-2011. An interdisciplinary view of underemployment was taken, including involuntary part-time, over-qualification, involuntary temporary work, low-wage employment and unemployment (Reynolds, 2012:8). The youth, defined as those aged 15-24 years, experienced a greater likelihood of labour under-utilisation through temporary work and minimum wages (Reynolds, 2012:11), compared with other employed aged 25-54 years.

As mentioned earlier, another objective measure to determine over-qualification is the standard deviation approach. Studies that used this measure (Groot, 1996; Groot and Van den Brink, 2000; Bauer, 2002) have yielded lower incidence of underemployment than subjective measures. Nonetheless, McGuinness (2006) raised the concern that the cut-off point (one standard above the mean) is arbitrary in nature. If a high proportion is educated, this will result in the mean and cut-off being raised hence under-estimating underemployment.

As far as studies using the subjective approaches are concerned, respondents were asked if they believed themselves to be underemployed in the study by Bonnal, Lira and Addy (2009), and it was found that the underemployment rates were $24.0 \%$ and $25.2 \%$ in 2004 and 2005 respectively in Alabama. McGuinness (2006) as well as Wilkens and Wooden (2011), in their review of the over-education literature found that subjective measures may have led to derivation of higher likelihood of under-employment than using objective measures. Issues arise from the quality of data collected, as workers may not have the best understanding of the requirements of the job in terms of qualification.

Few studies focused on examining the consequences of underemployment. First, Kazan (2012) examined how underemployment impacted the work organisations. Since the recession employers have been making use of more part-time staff, leading to the under-utilization of the workforce. A concern raised by Kazan (2012) was that organisations should seek to address the risks associated with the under-utilization of labour, such as low morale, workplace stress, and low productivity. On the other hand, Fleming and Kler (2008) found that across their six measures of satisfaction, over-qualified workers were less satisfied than their counterparts. Wilkens (2007) similarly found that amongst part-time workers, mean job satisfaction was lower.

\section{Empirical findings}

\subsection{Number of underemployed}

This section adopts the time-based and over-qualification approaches in determining the nature, extent and trends of underemployment in South Africa, using data from the 1995-1999 October Household Surveys (OHSs), 2000-2007 Labour Force Surveys (LFSs) and 2008-2014 Quarterly Labour Force Surveys (QLFSs) conducted by Stats SA. Unfortunately, as mentioned in Section 2.1, it was only since the introduction of QLFS in 2008 that the questions relevant to time-based underemployment have been asked. It can be seen from Figure 3 shows that the number of underemployed has been fluctuating between 520,000 and 700,000 since 2008. These underemployed accounts for $4-5 \%$ of all employed. 


\section{[INSERT FIGURE 3 ABOUT HERE]}

The other way in which one can measure underemployment is using the inadequate employment definition. As discussed in Section 2, there are quite a number of ways in which employees are generally restricted from productively performing their tasks or duties. These barriers could either be directly limiting their capacities or indirectly affecting their well-being. Over-education is one of the approaches to reflect this type of skills underutilization. Over-education implies a situation whereby an employee is employed in an occupation where the required educational attainment is below what the employee currently holds (McGuinness, 2006: 391).

In this paper two approaches are adopted to determine over-education. The first approach considers the educational requirement for each occupation category. Table A.1 in the Appendix outlines the required education level at each broad occupation category, as indicated in the Stats SA document "South African Standard Classification of Occupations" (SASCO). Hence, an employed worker is classified as underemployed if he/she is employed in an occupation where the required education level is below his/her educational attainment level. For example, if person A has a Bachelor degree but is employed under the clerks category (which only requires up to Matric qualification), he/she is classified as underemployed. Similarly, if someone with a Matric certificate is involved in an elementary occupation (which only requires primary education level up to Grade 7), he/she would also be classified as underemployed.

A possible drawback of this approach is that the educational requirement for each occupation remains unchanged in all surveys, however the employed have become more educated over the years (see Figure A.1 in the Appendix). Thus the share of employed that are considered underemployed according to this definition has nearly doubled due to the general level of education increasing. It is evidenced in Figure A.2, which shows that there is an upward trend in underemployment under this over-qualification approach, with the number of under-employed increasing from 1.5 million in 1995 to 4.3 million in the last quarter of 2014. On the other hand, the share of underemployed as a proportion of all employed increased from $15.7 \%$ to $27.9 \%$ during the same period. This outcome is quite different from the general trend observed in Figure 3 regarding time-related underemployment.

A second method to distinguish an individual as underemployed under the over-qualification approach is that the education years of someone in a particular occupation category is at least one standard deviation above the mean of the employed in this occupation category. As discussed in Section 2.3, Very little empirical work has been done using this approach. Figure 4 shows that there is no discernable trend in underemployment under this approach, with the number of under-employed fluctuating around 0.9 million in 1995 to 1.8 million in the last quarter of 2014. On the other hand, the share of underemployed as a proportion of all employed fluctuated around $6 \%$ to $15 \%$ during the same period.

[INSERT FIGURE 4 ABOUT HERE] 
For the remainder of this study, under-employed under this second over-qualification approach, along with the time-based unemployed, would be the focus of the empirical analysis. Finally, Table 1 concludes this sub-section by showing the total number of under-employed (from the two abovementioned approaches) as well as its share of all employed in 1995-2014. It can be seen that a downward trend could be observed in the 2008-2014 period (when it is possible to derive under-employed using both approaches), as the under-employed's share of total employed decreased from $15.6 \%$ to $11.4 \%$.

\section{[INSERT TABLE 1 ABOUT HERE]}

\subsection{Profile of underemployed}

Table 2 presents the demographic, province and broad industry categories of the following three groups of employed in 2008 and 2014: (1) underemployed derived under the time-based approach; (2) underemployed derived under the over-qualification approach; (3) other employed (who were not distinguished as underemployed in the two abovementioned approaches).

\section{[INSERT TABLE 2 ABOUT HERE]}

Firstly, it can be seen that for all three groups, the black share is the highest reflecting that a greater proportion of the underemployed were blacks. However, this share was clearly the lowest (just above $70 \%$ ) in both years for Group (3). The white share under the over-qualification definition is much higher and increases between the two years from $25.91 \%$ to $28.39 \%$. Secondly, males accounted for the lower share of underemployment at approximately $40 \%$ for Group (1). This finding perhaps signals that females are more willing to work extra hours. This could be due to the fact that women are highly associated with the involuntary part-time work. The male and female of underemployed appear more equitable in Group 2. In Group (3), the female share was lower $(41.31 \%$ and $42.88 \%)$ than the male share in both years. In addition, it the majority of employed in all three groups were aged 24-44 years at the time of the surveys.

Across both underemployment definitions, the majority of the underemployed resided in Gauteng, Kwa-Zulu Natal and Western Cape. Interestingly, they are also the provinces that typically have lower unemployment rates. This could point to a situation of underemployment rather than open unemployment as noted by Golub and Hayat (2014).

Information on area type was not available in QLFS 2008. In 2014, those residing in the urban formal areas accounted for the highest share of underemployed at 56.4\% and $85.6 \%$ for Group (1) and Group (2) respectively. This could be an indication of all those who migrate from rural to urban areas in search of work. When adequate work does not materialise, many are forced to enter informal work activities which is characterised by insecure wages, hours, and an underutilization of skills. Finally, the broad industry categories accounting for the greater share of underemployed are as follows: private households, community services, and wholesale and retail trade for Group (1); community services, financial intermediation, manufacturing, and private households for Group (2). 


\subsection{Econometric analysis on the likelihood of being underemployed}

The preceding analysis is limited in that it takes into account only one variable at a time when describing the characteristics of the underemployed. However, many variables act together to determine whether the employed person is classified as underemployed. Probit regressions were therefore run to estimate the marginal fixed effects (MFXs) of different potential influences on the likelihood of a worker being classified as underemployed (regardless of whether the worker was distinguished as underemployed under the time-based or over-qualification approach) in the fourth quarter 2008 and 2014. The independent variables in the regressions are the demographics (gender, race and age), years of work experience, geographical location (province), industry categories, whether employed in the public or private sector, formal or informal sector, or as employee or self-employed/employer. The results are presented in Table 3.

\section{[INSERT TABLE 3 ABOUT HERE]}

First of all, females were associated with a $1 \%$ greater likelihood of being underemployed relative to their male counterpart in 2008; however, the result was statistically significant only in 2008. Controlling for race, Indians in both years were significantly less likely to be underemployed relative to white people. Their prevalence decreased by 3 percentage points from $6.86 \%$ in 2008 to $3.47 \%$ in 2014 . On the other hand, Blacks were $3 \%$ significantly more likely to be underemployed than white people in 2008, whilst Coloureds were $2 \%$ significantly less likely to be underemployed relative to white people in 2014. There was a significant and concave relationship between age in years and the probability of being underemployed in both surveys. This implies that as one got to be a middle-aged worker, there was a greater likelihood to be underemployed.

Accounting for place of residence, in 2008 employed residing in the Northern Cape, Free State, Mpumalanga and KwaZulu-Natal provinces were more likely to be underemployed relative to those staying in the Western Cape. The MFX was greatest for KwaZulu-Natal. Those residing in Limpopo and Gauteng province were significantly less likely to be underemployed relative to those staying in the Western Cape. For the other provinces the results were insignificant. In 2014, only people staying in the Northern West province were significantly less likely to be underemployed than those in the Western Cape province, yet those from the Northern Cape and Eastern Cape provinces were significantly more likely to be underemployed relative to those in the Western Cape. For the other provinces the results were insignificant.

In both years, there was a significant convex relationship between years of experience and the likelihood of underemployment. This finding suggests that those employed with very fewer years of experience could be reluctantly under-employed (e.g. the youth employed), while those with longer years of experience may be the more elderly workers who opt to work shorter hours due to the fact that they are approaching retirement.

Accounting for the industry of the employed, those workers engaged in activities in the mining, manufacturing, wholesale and retail, transport, construction, finance and community services sectors were significantly less likely to be underemployed relative to those employed in the skilled 
agriculture sector in 2008. In 2014, only workers in the construction and the finance sectors were less to be underemployment to those in the agriculture sector. The private household sector employees in both years showed a significantly greater likelihood (more than 20\%) of being underemployed relative to those in the agricultural sector. It was only in 2014 that workers in the wholesale and retail sector were significantly more likely to be underemployed, and the other sectors' results were insignificant.

Finally, employees were significantly less likely to be underemployed in both years as compared to self-employed/employers, while those working in the informal and public sectors were significantly more likely to be underemployed.

\section{Conclusion}

Since 1994, the South African government has made huge investments and policy changes in order to improve labour productivity as well as the efficiency in the operation of the labour market. However, after two decades, the economy still shows a great slack in production and failure to fully assimilate all available labour. This raises questions like how much economic prosperity is lost due to the loss in the productive capacity. This paper had discussed the nature, level and trends of underemployment in South Africa. This was done to provide an understanding of the employment dynamics in the South African labour market.

The snapshot of time-based approach shows that $4 \%$ to $5 \%$ of employed are underemployed. Whilst for the inadequate employment approach fluctuated between $6 \%$ to $15 \%$ of employed to be underemployment. Under both definitions the prevalence of underemployment was greater on individuals who are blacks, females, urban formal dwellers, working in elementary occupations or domestic workers, in the manufacturing, wholesale and retail, transport and private household industries, and in the informal sector or public sector.

\section{References}

Ansah, J. W. (2012). Our jobs, our survival: A review of the national employment policy of Ghana. International Journal of Sociology and Anthropology. 5(4): 107-115.

Banerjee, A., Galiani, S., Levinsohn, J., McLaren, Z. and Woolard, I. (2008). Why has unemployment risen in the New South Africa? Economics of Transition Journal. 16(4): 715740 .

Barker, F. (2007). The South African Labour Market: Theory and Practice. 5th edition. Pretoria: Van Schaik Publishers.

Bauer, T. (2002). Educational mismatch and wages: a panel analysis. Economics of Education Review. 21(3): 221-229.

Bell, D. N. F. and Blanchflower, D. G. (2013). How to Measure Underemployment? Peterson Institute for International Economics Working Paper Series 13-7. Washington, DC: Peterson Institute for International Economics 
Bhorat, H. (2009). Unemployment in South Africa: descriptors and determinants. Conference proceedings, the Fourth IZA/World Bank Conference on Employment and Development, May 2009.

Bhorat, H. (2012). A nation in search of jobs: six possible policy suggestions for employment creation in South Africa. Development Policy Research Unit Working Paper 12/150. Cape Town: Development Policy Research Unit.

Bonnal, M., Lira, C. and Addy, S.N. (2009). Underemployment and local employment dynamics: New evidence. The Review of Regional Studies. 39(3): 317-335.

Cam, S. (2014). The underemployed: Evidence from the UK labour force survey. Cardiff School of Social Sciences Working Paper Series No.152. Cardiff: School of Social Sciences.

Clogg, C.C., Sullivan, T.A. and Mutchler, J.E. (1986). Measuring underemployment and inequality in the work force. Social Indicators Research. 18(4): 375-393.

Denu, B., Tekeste, A. and Van der Deijl, H. (2005). Characteristics of youth unemployment, underemployment and inadequate employment in Ethiopia. Employment Strategy Papers. Employment Policies Unit. 2005/07.

Felstead, A. and Green, F. (2013). Skills in focus: underutilization, overqualification and skills mismatch: patterns and trends. Edinburgh: Joint Skills Committee.

Fleming, C.M. and Kler, P. (2008). I'm too clever for this job: a Bivariate Probit Analysis on Overeducation and Job Satisfaction in Australia. Applied Economics. 40(9): 1123-1138.

Glyde, G.P. (1977). Under-employment: Definition and Causes. Journal of Economic Issues. 11(2): 245-261.

Golub, S. and Hayat, F. (2014). Employment, unemployment, and underemployment in Africa. WIDER Working Paper 2014/014. Helsinki: World Institute for Development Economics Research (WIDER).

Greenwood, M. A. (1999). International definitions and prospects of underemployment statistics. Proceedings for the Seminario sobre Subempleo, Bogota, 8-12 November.

Groot, W. (1996). The incidence and returns to overeducation in the UK. Applied Economics. 28(10): 1345-1350.

Groot, W. and Van den Brink, H. (2000). Skills mismatches in the Dutch labor market. International Journal of Manpower. 21(8): 584-595.

Kazan, M. (2012). Underemployment: Implications for organizations. Economic Research Institute. Redmond: Economic Research Institute.

Kingdon, G.G. and Knight, J. (2004). Unemployment in South Africa: the nature of the beast. World Development. 32(3): 391-408.

Mathebula, I. (2013). The determinants of time-related underemployment in South Africa. Pretoria: Statistics South Africa.

McGuinness, S. (2006). Over-education in the labour market. Journal of Economic Surveys. 20(3): 387-481.

McKee-Ryan, F.M. and Harvey, J. (2011). "I Have a Job, But..." A Review of underemployment. Journal of Management. 37(4): 962-996.

Mosca, I. and Wright, R.E. (2011). Is graduate under-employment persistent? Evidence from the United Kingdom. The Institute for the Study of Labour (IZA) Discussion Paper Series No. 6177. Bonn: The Institute for the Study of Labour. 
Organization for Economic Cooperation and Development (OECD). (2014). Preventing unemployment and underemployment from becoming structural. Report prepared for the G20 Labour and Employment Ministerial Meeting, Melbourne, 10-11 September.

Reynolds, L. (2012). The incidence and persistence of youth underemployment: The Canadian Context. Public Policy and Governance Review. 4(1): 5-18.

Ruiz-Ouintanilla, S.A. and Claes, R. (1994). Determinants of underemployment during the early career: a longitudinal multi-country study: Centre for Advanced Human Resource Studies. Working Paper Series. Ithaca: Cornell University.

Schoeman, C.H., Botha, I. and Blaauw, P.F. (2010). Labour conflict and the persistence of macro underemployment in South Africa. South African Journal of Economic and Management Sciences. 13(3): 272-292.

Sengenberger, W. (2011). Beyond the measurement of unemployment and underemployment: The case for extending and amending labour market statistic. Geneva: International Labour Organisation.

Slack, T and Jensen, L. (2002). Race, Ethnicity, and Underemployment in Nonmetropolitan America: A 30-Year Profile. Journal of Rural Sociology. 67(2): 208-233.

Tam, H. (2010). Characteristics of the underemployed and overemployed in the UK. Economic and Labour Market Review. 4(7): 8-20.

Walling, A. and Clancy, G. (2010). Underemployment in the UK labour market. Economic and Labour Market Review. 4(2): 16-24.

Wilkins, R. (2007). The consequences of underemployment for the underemployed. Journal of Industrial Relations. 49(2): 247-275.

Wilkins, R. and Wooden, M. (2011). Economic Approaches to Studying underemployment. In Feldman, D. \& Maynard, D. (eds.), Underemployment: Psychological Economic and Social Challenges. New York: Springer.

Yu, D. (2009). The comparability of Labour Force Survey (LFS) and Quarterly Labour Force Survey (QLFS). Stellenbosch Economic Working Papers 08/09. Stellenbosch: Stellenbosch University.

\section{Appendix}

[INSERT TABLE A.1 ABOUT HERE]

[INSERT FIGURE A.1 ABOUT HERE]

[INSERT FIGURE A.2 ABOUT HERE] 
Figure 1: Underemployment: Time-based approach

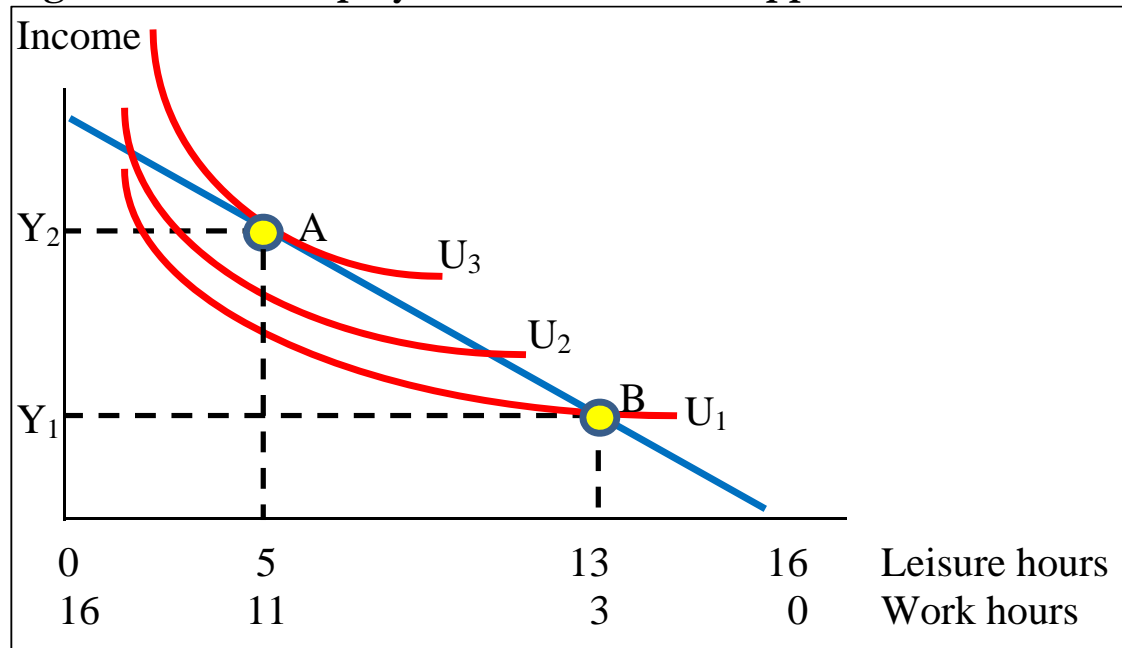

Figure 2: Underemployment: Over-qualification approach

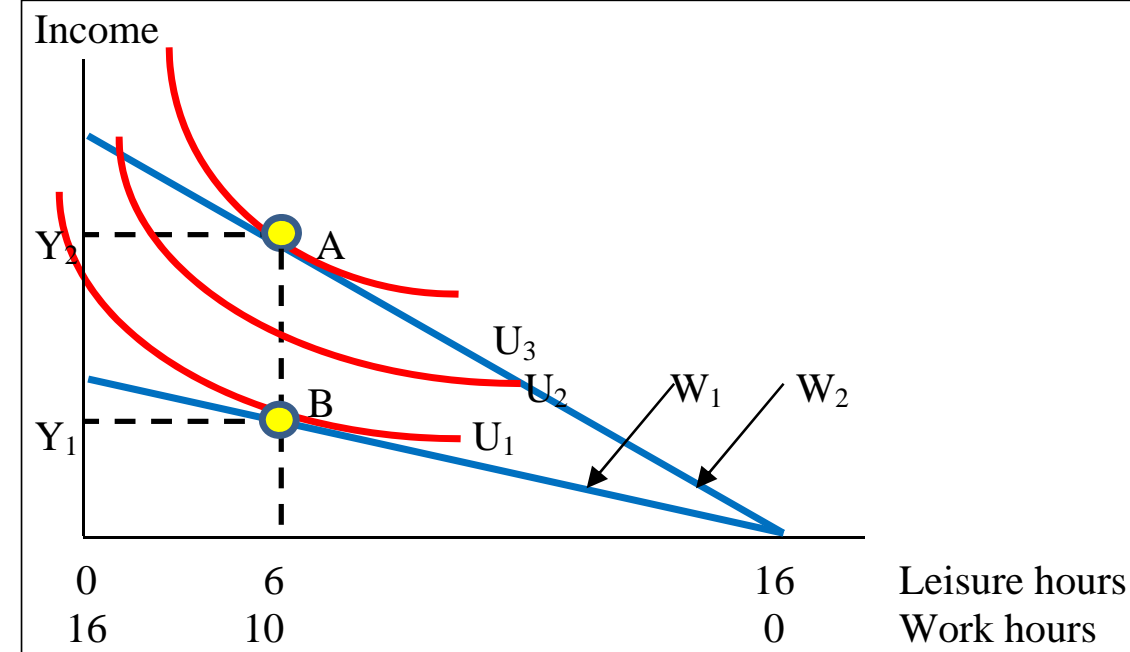


Figure 3: Underemployment derived from the time-based approach, 2008-2014

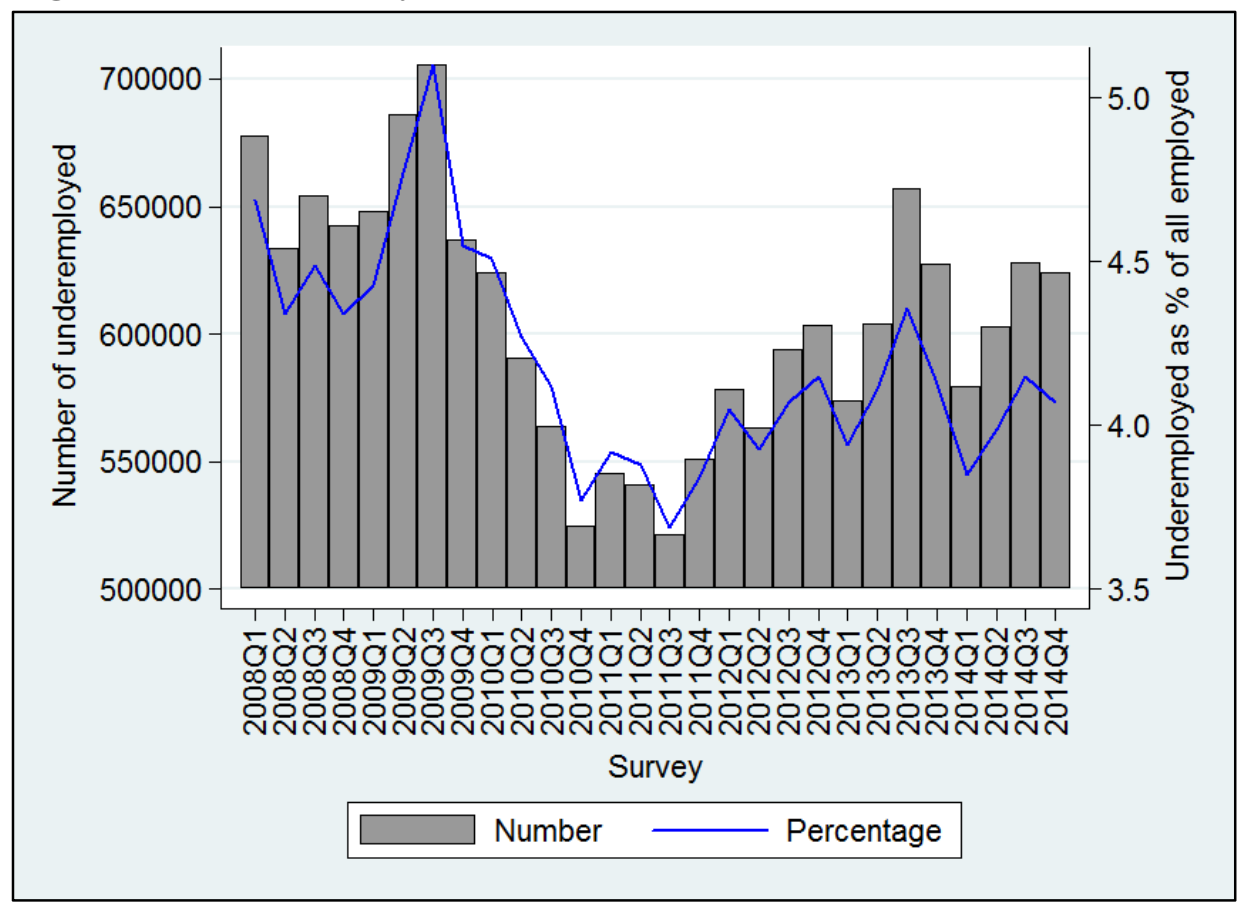

Source: Own calculations using QLFS 2008-2014 data.

Figure 4: Underemployment derived from the over-qualification approach (years of education exceed one standard deviation of the mean years of education of the relevant occupation category), 1995-2014

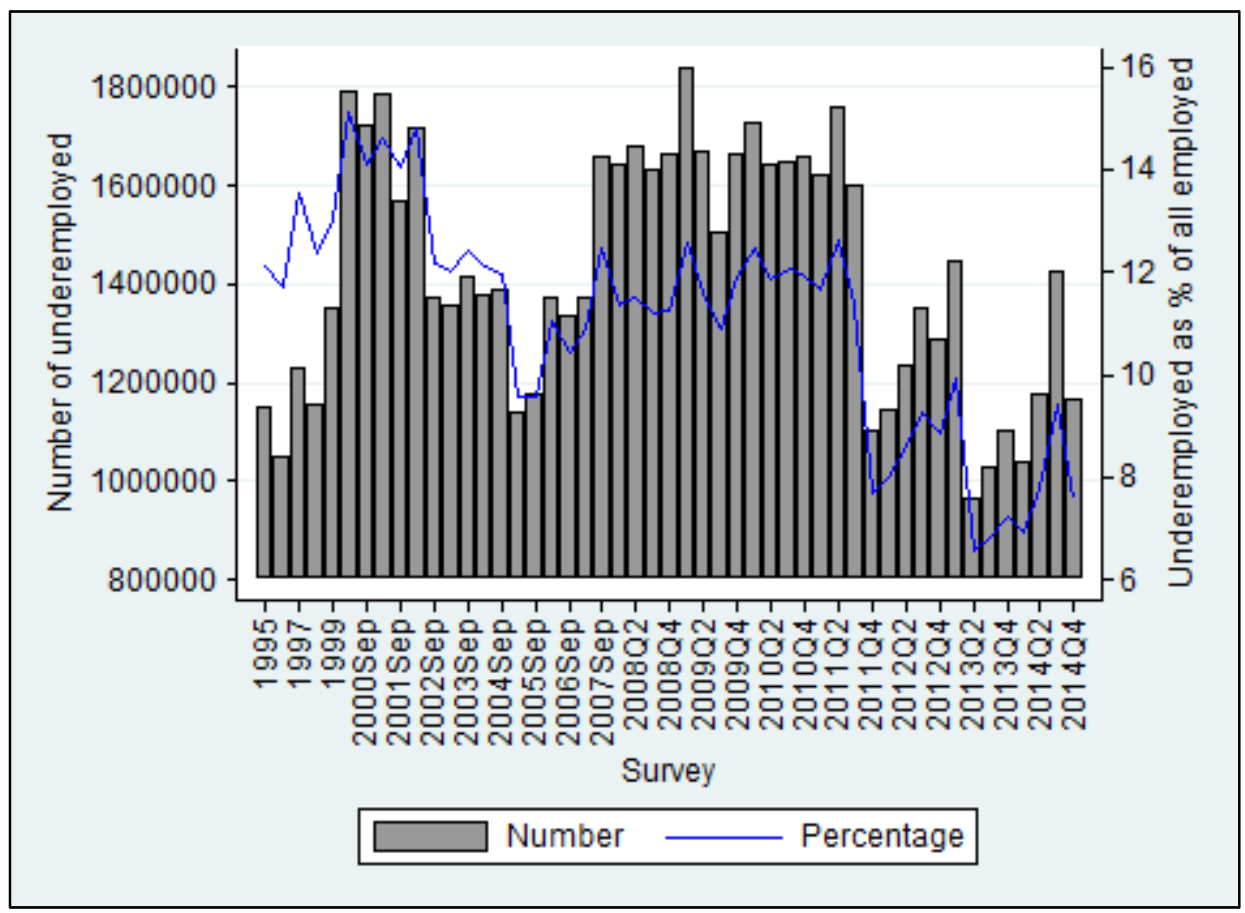

Source: Own calculations using OHS 1995-1999, LFS 2000-2007 and QLFS 2008-2014 data. 
Table 1: Number of underemployed, 1995-2014

\begin{tabular}{|c|c|c|c|c|c|}
\hline & {$[\mathrm{A}]$} & {$[\mathrm{B}]$} & [C] & {$[\mathrm{D}]=[\mathrm{A}]+[\mathrm{B}]+[\mathrm{C}]$} & As $\%$ of all employed \\
\hline OHS1995 & \multirow{21}{*}{ N/A } & 1152768 & \multirow{21}{*}{$\mathrm{N} / \mathrm{A}$} & 1152768 & $12.1 \%$ \\
\hline OHS1996 & & 1051655 & & 1051655 & $11.7 \%$ \\
\hline OHS1997 & & 1231219 & & 1231219 & $13.5 \%$ \\
\hline OHS1998 & & 1157055 & & 1157055 & $12.3 \%$ \\
\hline OHS1999 & & 1350448 & & 1350448 & $13.0 \%$ \\
\hline LFS2000a & & 1793609 & & 1793609 & $15.1 \%$ \\
\hline LFS2000b & & 1722035 & & 1722035 & $14.1 \%$ \\
\hline LFS2001a & & 1788094 & & 1788094 & $14.6 \%$ \\
\hline LFS2001b & & 1570733 & & 1570733 & $14.1 \%$ \\
\hline LFS2002a & & 1717663 & & 1717663 & $14.8 \%$ \\
\hline LFS2002b & & 1372974 & & 1372974 & $12.2 \%$ \\
\hline LFS2003a & & 1356137 & & 1356137 & $12.0 \%$ \\
\hline LFS2003b & & 1417385 & & 1417385 & $12.4 \%$ \\
\hline LFS2004a & & 1378677 & & 1378677 & $12.1 \%$ \\
\hline LFS2004b & & 1391350 & & 1391350 & $12.0 \%$ \\
\hline LFS2005a & & 1138847 & & 1138847 & $9.6 \%$ \\
\hline LFS2005b & & 1177002 & & 1177002 & $9.6 \%$ \\
\hline LFS2006a & & 1374196 & & 1374196 & $11.0 \%$ \\
\hline LFS2006b & & 1335246 & & 1335246 & $10.4 \%$ \\
\hline LFS2007a & & 1375242 & & 1375242 & $10.9 \%$ \\
\hline LFS2007b & & 1657894 & & 1657894 & $12.5 \%$ \\
\hline QLFS2008Q1 & 447721 & 1571056 & 71124 & 2248556 & $15.6 \%$ \\
\hline QLFS2008Q2 & 413774 & 1609508 & 70566 & 2243095 & $15.4 \%$ \\
\hline QLFS2008Q3 & 425537 & 1543005 & 88183 & 2197348 & $15.1 \%$ \\
\hline QLFS2008Q4 & 395034 & 1581939 & 81374 & 2224278 & $15.0 \%$ \\
\hline QLFS2009Q1 & 398626 & 1740808 & 100942 & 2388697 & $16.3 \%$ \\
\hline QLFS2009Q2 & 413595 & 1570202 & 101285 & 2256319 & $15.7 \%$ \\
\hline QLFS2009Q3 & 413463 & 1429972 & 74715 & 2135284 & $15.4 \%$ \\
\hline QLFS2009Q4 & 365310 & 1589426 & 75831 & 2226340 & $15.9 \%$ \\
\hline QLFS2010Q1 & 370676 & 1663576 & 62804 & 2287480 & $16.6 \%$ \\
\hline QLFS2010Q2 & 354764 & 1576105 & 65591 & 2166930 & $15.7 \%$ \\
\hline QLFS2010Q3 & 317648 & 1581854 & 65778 & 2145606 & $15.7 \%$ \\
\hline QLFS2010Q4 & 309833 & 1597565 & 59252 & 2122093 & $15.2 \%$ \\
\hline QLFS2011Q1 & 308552 & 1564939 & 54546 & 2110599 & $15.2 \%$ \\
\hline QLFS2011Q2 & 311314 & 1699214 & 61809 & 2240102 & $16.1 \%$ \\
\hline QLFS2011Q3 & 319193 & 1557089 & 45501 & 2078506 & $14.7 \%$ \\
\hline QLFS2011Q4 & 305845 & 1066274 & 34348 & 1617447 & $11.3 \%$ \\
\hline QLFS2012Q1 & 337366 & 1111986 & 33858 & 1690399 & $11.8 \%$ \\
\hline QLFS2012Q2 & 322169 & 1193061 & 39942 & 1756305 & $12.2 \%$ \\
\hline QLFS2012Q3 & 339561 & 1320651 & 32137 & 1914516 & $13.1 \%$ \\
\hline QLFS2012Q4 & 336456 & 1258502 & 29448 & 1862196 & $12.8 \%$ \\
\hline QFLS2013Q1 & 313279 & 1409292 & 38537 & 1983014 & $13.6 \%$ \\
\hline QLFS2013Q2 & 340462 & 930212 & 34273 & 1534487 & $10.4 \%$ \\
\hline QLFS2013Q3 & 377704 & 997689 & 31596 & 1654559 & $11.0 \%$ \\
\hline QLFS2013Q4 & 377550 & 1064455 & 37884 & 1691727 & $11.1 \%$ \\
\hline QLFS2014Q1 & 329415 & 1015822 & 25119 & 1595446 & $10.6 \%$ \\
\hline QLFS2014Q2 & 335901 & 1151736 & 24578 & 1754356 & $11.6 \%$ \\
\hline QLFS2014Q3 & 349691 & 1397171 & 28509 & 2025006 & $13.4 \%$ \\
\hline QLFS2014Q4 & 340633 & 1130976 & 33127 & 1755096 & $11.4 \%$ \\
\hline
\end{tabular}

[A]: Time-based definition only

[B]: Over-qualification definition only (years of education exceed one standard deviation of the mean years of education of the relevant occupation category)

$[C]$ : Both definitions 
Table 2: Characteristics of the various groups of employed, 2008 vs. 2014

\begin{tabular}{|c|c|c|c|c|c|c|}
\hline & \multicolumn{2}{|c|}{$\begin{array}{l}\text { Underemployed: } \\
\text { Time-based } \\
\text { definition }\end{array}$} & \multicolumn{2}{|c|}{$\begin{array}{c}\text { Underemployed: } \\
\text { Over-qualification }\end{array}$} & \multicolumn{2}{|c|}{$\begin{array}{c}\text { Other employed } \\
\text { (Not } \\
\text { underemployed) }\end{array}$} \\
\hline & 2008 & 2014 & 2008 & 2014 & 2008 & 2014 \\
\hline \multicolumn{7}{|l|}{ Race } \\
\hline Black & $85.40 \%$ & $85.83 \%$ & $64.28 \%$ & $60.50 \%$ & $71.04 \%$ & $73.63 \%$ \\
\hline Coloured & $8.57 \%$ & $10.29 \%$ & $6.67 \%$ & $5.96 \%$ & $11.42 \%$ & $11.15 \%$ \\
\hline Indian & $1.74 \%$ & $0.74 \%$ & $3.14 \%$ & $5.15 \%$ & $3.37 \%$ & $3.23 \%$ \\
\hline White & $4.29 \%$ & $3.14 \%$ & $25.91 \%$ & $28.39 \%$ & $14.18 \%$ & $11.99 \%$ \\
\hline \multicolumn{7}{|l|}{ Gender } \\
\hline Male & $39.69 \%$ & $40.95 \%$ & $49.57 \%$ & $52.85 \%$ & $58.69 \%$ & $57.12 \%$ \\
\hline Female & $60.31 \%$ & $59.05 \%$ & $50.43 \%$ & $47.15 \%$ & $41.31 \%$ & $42.88 \%$ \\
\hline \multicolumn{7}{|l|}{ Age } \\
\hline $15-24$ years & $14.36 \%$ & $9.10 \%$ & $10.71 \%$ & $5.20 \%$ & $11.03 \%$ & $8.56 \%$ \\
\hline $25-34$ years & $31.44 \%$ & $29.14 \%$ & $35.40 \%$ & $32.44 \%$ & $33.17 \%$ & $31.35 \%$ \\
\hline $35-44$ years & $27.81 \%$ & $28.52 \%$ & $30.96 \%$ & $34.47 \%$ & $27.83 \%$ & $30.66 \%$ \\
\hline 45-54 years & $19.87 \%$ & $25.09 \%$ & $16.68 \%$ & $19.19 \%$ & $19.59 \%$ & $20.08 \%$ \\
\hline $55-65$ years & $6.52 \%$ & $8.15 \%$ & $6.25 \%$ & $8.71 \%$ & $8.38 \%$ & $9.34 \%$ \\
\hline Mean (years) & 36.80 & 38.95 & 36.80 & 39.04 & 37.62 & 38.59 \\
\hline \multicolumn{7}{|l|}{ Province } \\
\hline Western Cape & $11.70 \%$ & $12.35 \%$ & $13.46 \%$ & $14.28 \%$ & $14.07 \%$ & $14.63 \%$ \\
\hline Eastern Cape & $10.35 \%$ & $14.93 \%$ & $8.13 \%$ & $7.81 \%$ & $9.14 \%$ & $8.74 \%$ \\
\hline Northern Cape & $2.47 \%$ & $3.08 \%$ & $1.60 \%$ & $1.98 \%$ & $2.21 \%$ & $1.98 \%$ \\
\hline Free State & $7.56 \%$ & $6.50 \%$ & $5.19 \%$ & $4.38 \%$ & $5.64 \%$ & $4.92 \%$ \\
\hline KwaZulu-Natal & $25.84 \%$ & $18.23 \%$ & $16.10 \%$ & $12.87 \%$ & $17.31 \%$ & $16.65 \%$ \\
\hline North West & $4.87 \%$ & $4.93 \%$ & $5.00 \%$ & $3.78 \%$ & $6.41 \%$ & $6.20 \%$ \\
\hline Gauteng & $24.23 \%$ & $25.38 \%$ & $38.39 \%$ & $42.01 \%$ & $31.71 \%$ & $31.24 \%$ \\
\hline Mpumalanga & $8.57 \%$ & $8.30 \%$ & $6.29 \%$ & $6.22 \%$ & $7.03 \%$ & $7.56 \%$ \\
\hline Limpopo & $4.39 \%$ & $6.30 \%$ & $5.84 \%$ & $6.66 \%$ & $6.47 \%$ & $8.09 \%$ \\
\hline \multicolumn{7}{|l|}{ Area type } \\
\hline Urban formal & $\mathrm{N} / \mathrm{A}$ & $56.42 \%$ & $\mathrm{~N} / \mathrm{A}$ & $85.60 \%$ & $\mathrm{~N} / \mathrm{A}$ & $67.24 \%$ \\
\hline Urban informal & $\mathrm{N} / \mathrm{A}$ & $12.07 \%$ & $\mathrm{~N} / \mathrm{A}$ & $3.73 \%$ & $\mathrm{~N} / \mathrm{A}$ & $9.76 \%$ \\
\hline Tribal areas & $\mathrm{N} / \mathrm{A}$ & $28.44 \%$ & $\mathrm{~N} / \mathrm{A}$ & $8.97 \%$ & $\mathrm{~N} / \mathrm{A}$ & $18.05 \%$ \\
\hline Rural formal & $\mathrm{N} / \mathrm{A}$ & $3.08 \%$ & $\mathrm{~N} / \mathrm{A}$ & $1.70 \%$ & $\mathrm{~N} / \mathrm{A}$ & $4.95 \%$ \\
\hline \multicolumn{7}{|l|}{ Broad industry category } \\
\hline Agriculture & $3.35 \%$ & $1.79 \%$ & $3.31 \%$ & $0.92 \%$ & $6.03 \%$ & $5.08 \%$ \\
\hline Mining & $0.10 \%$ & $0.07 \%$ & $2.19 \%$ & $4.07 \%$ & $2.56 \%$ & $2.82 \%$ \\
\hline Manufacturing & $6.80 \%$ & $3.67 \%$ & $11.93 \%$ & $12.63 \%$ & $14.99 \%$ & $11.88 \%$ \\
\hline Electricity & $0.28 \%$ & $0.03 \%$ & $1.19 \%$ & $1.82 \%$ & $0.66 \%$ & $0.71 \%$ \\
\hline Construction & $9.12 \%$ & $11.51 \%$ & $4.47 \%$ & $5.52 \%$ & $8.78 \%$ & $8.32 \%$ \\
\hline Wholesale \& retail trade & $20.28 \%$ & $16.73 \%$ & $16.87 \%$ & $8.66 \%$ & $23.64 \%$ & $22.44 \%$ \\
\hline Transport & $3.40 \%$ & $2.48 \%$ & $4.35 \%$ & $5.97 \%$ & $5.92 \%$ & $6.32 \%$ \\
\hline Financial intermediation & $6.00 \%$ & $6.52 \%$ & $13.98 \%$ & $15.45 \%$ & $12.26 \%$ & $13.54 \%$ \\
\hline Community services & $14.12 \%$ & $22.55 \%$ & $28.28 \%$ & $32.79 \%$ & $17.97 \%$ & $22.18 \%$ \\
\hline Private households & $36.55 \%$ & $34.59 \%$ & $13.31 \%$ & $12.04 \%$ & $7.18 \%$ & $6.68 \%$ \\
\hline Others & $0.00 \%$ & $0.06 \%$ & $0.10 \%$ & $0.14 \%$ & $0.01 \%$ & $0.01 \%$ \\
\hline
\end{tabular}

Source: Own calculations using QLFS 2008Q1-Q4 and 2014Q1-Q4 data.

Note: The area type variable is not available in QLFS 2008. 
Table 3: Probit regressions on underemployment likelihood of employed, 2008 and 2014

\begin{tabular}{|l|r|r|}
\hline \multirow{2}{*}{ Explanatory variables } & \multicolumn{2}{|c|}{ Marginal fixed effects } \\
\cline { 2 - 3 } & QLFS 2008Q4 & QLFS 2014Q4 \\
\hline Gender: Female & $0.0144^{* * *}$ & 0.0083 \\
\hline Race: Black & $0.0276^{* * *}$ & -0.0048 \\
\hline Race: Coloured & -0.0055 & $-0.0248^{* *}$ \\
\hline Race: Indian & $-0.0686^{* * *}$ & $-0.0347^{* *}$ \\
\hline Age in years & $0.0934^{* * *}$ & $0.0926^{* * *}$ \\
\hline Age in years squared & $-0.0005^{* * *}$ & $-0.0007^{* * *}$ \\
\hline Province: Eastern Cape & 0.0079 & $0.0324^{* * *}$ \\
\hline Province: Northern Cape & $0.0244^{* *}$ & $0.0430^{* * *}$ \\
\hline Province: Free State & $0.0287^{* * *}$ & 0.0010 \\
\hline Province: KwaZulu-Natal & $0.0337^{* * *}$ & 0.0007 \\
\hline Province: North West & -0.0177 & $-0.0247^{* *}$ \\
\hline Province: Gauteng & $-0.0155^{*}$ & 0.0013 \\
\hline Province: Mpumalanga & $0.0185^{*}$ & 0.0092 \\
\hline Province: Limpopo & $-0.0239^{* *}$ & -0.0182 \\
\hline Years of experience & $-0.0769^{* * *}$ & $-0.0687^{* * *}$ \\
\hline Years of experience squared & $0.0006^{* * *}$ & $0.0006^{* * *}$ \\
\hline Industry: Mining & $-0.0552^{* * *}$ & 0.0285 \\
\hline Industry: Manufacturing & $-0.0630^{* * *}$ & -0.0021 \\
\hline Industry: Water \& Electricity & -0.0250 & 0.0114 \\
\hline Industry: Wholesale \& Retail & $-0.0421^{* * *}$ & $0.0340^{*}$ \\
\hline Industry: Construction & $-0.0823^{* * *}$ & $-0.0438^{* * *}$ \\
\hline Industry: Transport & $-0.0871^{* * *}$ & -0.0123 \\
\hline Industry: Finance & $-0.1061^{* * *}$ & $-0.0340^{*}$ \\
\hline Industry: Community services & $-0.0830^{* * *}$ & -0.0183 \\
\hline Industry: Private households & $0.2308^{* * *}$ & $0.2106^{* * *}$ \\
\hline Employee & $-0.0323^{* * *}$ & $-0.0322^{* * *}$ \\
\hline Informal sector & $0.0943^{* * *}$ & $0.0739^{* * *}$ \\
\hline Public sector & $0.0268^{* * *}$ & $0.0460^{* * *}$ \\
\hline & & \\
\hline Sample size & 24410 & 20663 \\
\hline Pseudo R2 & 0.2051 & 0.1882 \\
\hline Prob. > Chi-squared & 0.0000 & 0.0000 \\
\hline Observed probability & 0.0975 & 0.0738 \\
\hline Predicted probability (at x-bar) & (15ni & \\
\hline
\end{tabular}

*** Significant at $1 \% \quad * *$ Significant at $5 \% \quad *$ Significant at $10 \%$

Source: Own calculations using QLFS 2008Q4 and 2014Q4 data.

Reference groups: Gender: Male; race: White; province: Western Cape; occupation category: Any category other than elementary occupation and domestic worker; industry category: skilled agricultural worker 
Table A.1: Distinction of underemployed under the over-qualification definition

\begin{tabular}{|l|l|l|}
\hline \multicolumn{1}{|c|}{ Broad occupation category } & \multicolumn{1}{c|}{ Skills level } & \multicolumn{1}{c|}{ Education level required } \\
\hline Legislators, senior officials and managers & Most highly-skilled & Tertiary (degree or above) \\
\hline Professionals & Most highly-skilled & Tertiary (degree or above) \\
\hline Technicians and associate professionals & Highly-skilled & $\begin{array}{l}\text { Tertiary } \\
\text { (NOT equivalent to degree) }\end{array}$ \\
\hline Clerks & Semi-skilled & Secondary (Up to Matric) \\
\hline Service workers and shop and market sales workers & Semi-skilled & Secondary (Up to Matric) \\
\hline Skilled agricultural and fishery worker & Semi-skilled & Secondary (Up to Matric) \\
\hline Craft and related trade workers & Semi-skilled & Secondary (Up to Matric) \\
\hline Plant and machinery operators and assemblers & Semi-skilled & Secondary (Up to Matric) \\
\hline Elementary occupations & Unskilled & Primary (Up to Grade 7) \\
\hline Domestic workers & Unskilled & Primary (Up to Grade 7) \\
\hline
\end{tabular}

Source: South African Standard Classification of Occupations (SASCO), Stats SA. 
Figure A.1: Means years of education of employed in all race groups, 1995 - 2014

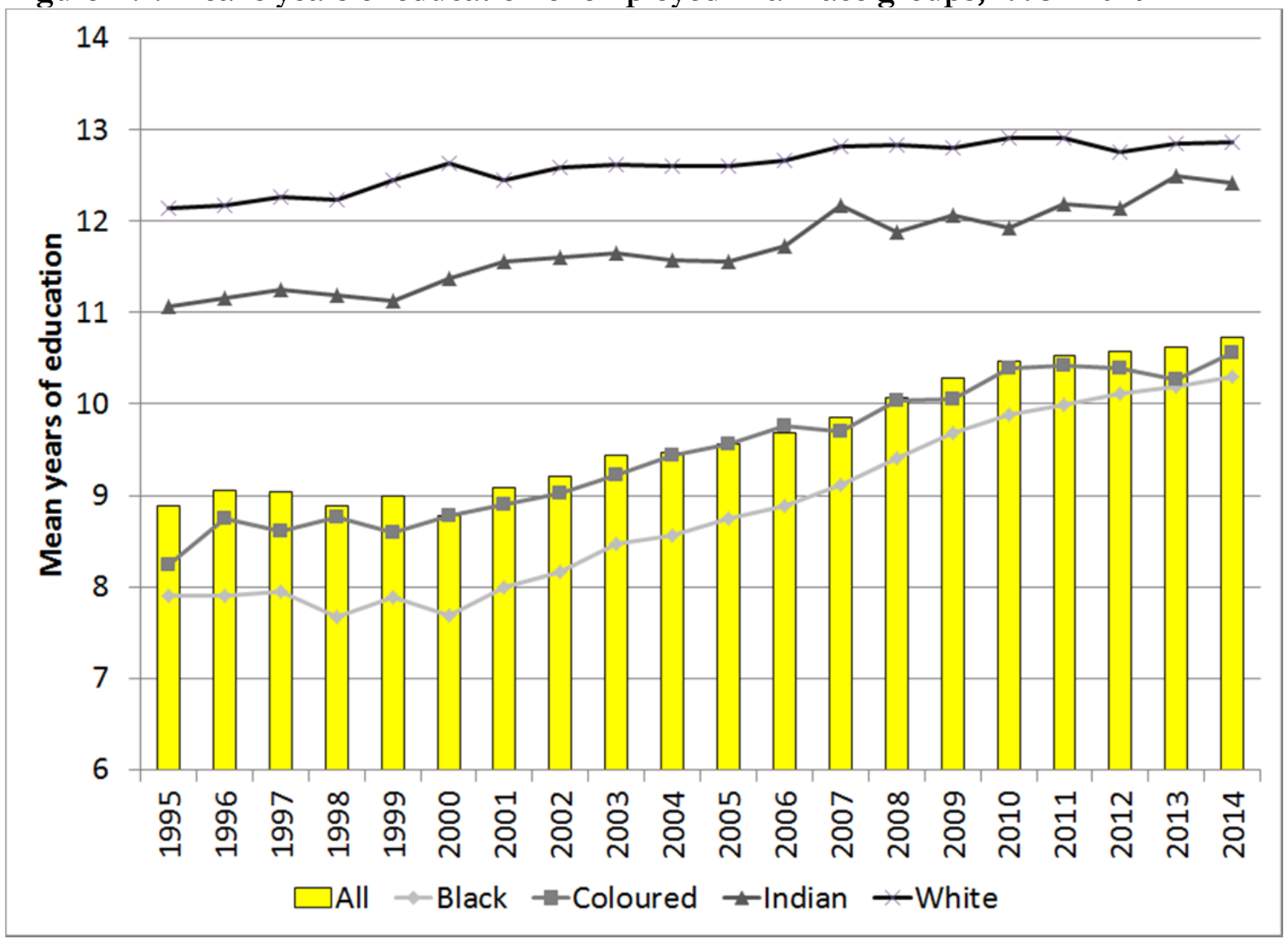

Source: Own calculations using OHS 1995-1999, LFS 2000-2007 and QLFS 2008-2014 data.

Figure A.2: Underemployment derived from the over-qualification approach (years of education exceed the required level of education in the relevant broad occupation category), 1995-2014

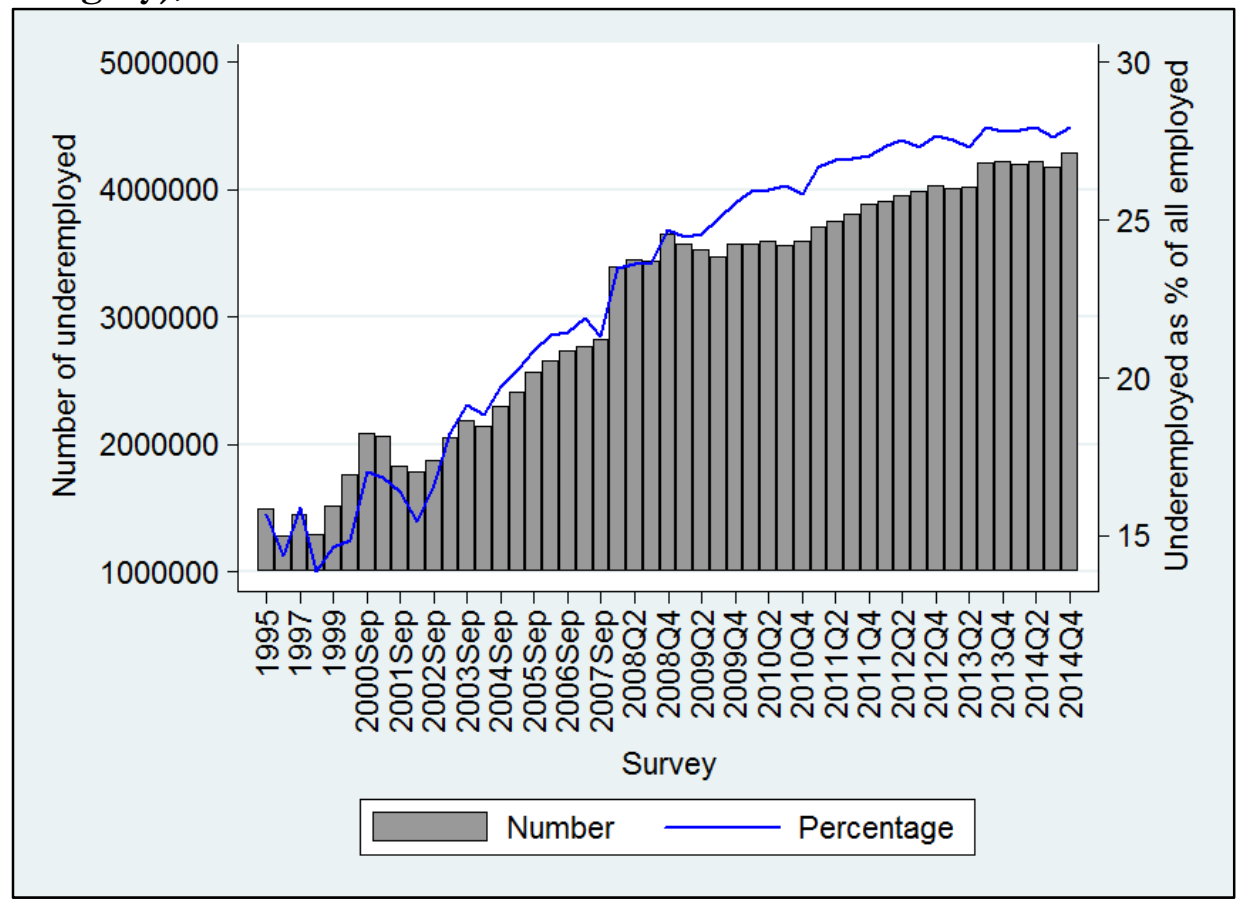

Source: Own calculations using OHS 1995-1999, LFS 2000-2007 and QLFS 2008-2014 data. 